\title{
Balkanilaisen musiikin segâh-pohjaisten moodien analyysimallit
}

Tässä artikkelissa käsittelen muusikoiden ja erityisesti musiikintutkijoiden asteikkopohjaisia analyysimalleja, joita he ovat soveltaneet osmanien taidemusiikin makam segâhin, makam müstearin ja makam hüzzamin* johdannaisiin Balkanin eri musiikkikulttuureissa. ${ }^{1}$ Artikkelin painopiste on kreikkalaisessa musiikissa. Segâh, müstear ja hüzzam ovat sukulaismakameja, joilla on sama finalissävel. Näiden makamien kiinnostavuus on siinä, että länsimaisen taidemusiikkiperinteen näkökulmasta niiden balkanilaiset, soinnutetut muodot käyttäytyvät varsin oudolla tavalla. Hahmoteltuani moodien analyysiongelmia esittelen niihin oman ratkaisuni.

Kansanmusiikintutkijat ovat pitäneet asteikkojen pohjalta tehtyä luokittelua tärkeänä sävelmätutkimuksen apukeinona (ks. Cazden 1971, 45-46; Elschek 1977). Varsinkin tieteenalan alkuaikoina asteikkoja pidettiin niin tärkeinä, että niiden empiiriseltä kannalta alisteinen suhde melodiaan pyrki unohtumaan. Niinpä skaaloja itsekin laajalti tutkinut Erich M. von Hornbostel joutui huomauttamaan merkittävässä artikkelissaan Melodie und Skala (Hornbostel 1913, 11), että asteikko on ennemmin melodian abstraktio kuin sen edeltäjä.

Hornbostel esitti huomionsa aikana, jolloin eurooppalainen moodikäsitys painotti moodin luokittelevaa ja asteikkoluonnetta. Harold S. Powers (1980, 377) on analysoinut asteikon ja melodian suhdetta moodin eri määritelmien avulla. Hänen mukaansa moodi voidaan käsittää joko täsmennetyksi asteikoksi tai yleistetyksi sävelmäksi. Musiikillinen tai kulttuurikonteksti saattaa sallia kummankin määritelmän yhtaikaisen käytön. Mikäli asteikon ja sävelmän ajatellaan olevan melodian ennaltamääräämisen ääripisteet, suurin osa niiden välimaastoa kuuluu tavalla tai toisella moodin alueeseen. Moodin ilmeneminen musiikissa edellyttää sävelkorkeuksien jonkinasteista hierarkiaa tai rajoitettua esiintymisjärjestystä. Musiikkikappaleen moodi ei voi olla niin rajattu, että sitä voisi kutsua kappaleen sävelmäksi. Moodi on aina vähintään melodiatyyppi tai -malli, ei koskaan vain ennaltamäärätty sävelmä. Kun moodit tulkitaan ensi-

\footnotetext{
* Vierasperäiset sanat on kursivoitu vain ensimmäisellä esiintymiskerralla (toim. huom.).

1 Balkan määritellään tavallisesti valtiollisten rajojen mukaan, mikä jättää Romanian alueen ulkopuolelle. Koska etelä- ja itäromanialainen kansanmusiikki sisältää runsaasti osmanivaikutteita, viittaan myös romanialaisten tutkijoiden töihin.
} 
sijaisesti asteikkomaisiksi, niitä käytetään musiikkikokonaisuuksien luokitteluun ideaalityyppeihin. Kun taas painotetaan moodien melodisia puolia, moodit nähdään säveltämisen ja improvisoinnin ohjeina ja normeina.

Moodin käsitehistoria voidaan jakaa kahteen kehityskauteen. Vielä 1800-luvulla 'moodi' merkitsi eurooppalaisissa kielissä asteikkoa, jota sävelmän päättävä tai päätössoinnun perussävelenä toimiva toonika hallitsi. Duuri- ja molliasteikkoa sekä kirkkosävellajeja voidaan pitää tässä mielessä moodeina yhä nykyäänkin. Kansanmusiikintutkimuksen alkuaikoina moodin asteikkomerkitystä sovellettiin myös ulkoeurooppalaisiin musiikkikulttuureihin. Eurooppalaiset musiikintutkijat kiinnostuivat asteikkomoodin ja sävelmän välisestä harmaasta alueesta vasta 1900-luvulla. Juutalaisen synagogalaulun ja itäisen kirkkolaulun tutkijat olivat uranuurtajia, jotka alkoivat laajentaa moodin käsitettä. Erityisesti Abraham Idelsohnin (1914, 11-12; 1929, 24-25) kirjoitukset olivat tärkeitä uuden moodikäsityksen levittäjiä. Monet länsimaiset musiikintutkijat alkoivat pitää ragaa, makamia ja kreikkalaisen kirkkomusiikin ekhosia asteikko- ja melodiatyypin välimaastoon sijoittuvina ilmiöinä tai niiden yhdistelminä. ${ }^{2}$ (Powers 1980, 422-423; idem. 1992, 212-215.)

\section{Luokitteluperusteita}

Länsimaisen musiikin teoriassa skaalat kuvataan oktaavin alueella siten, että niiden rakenteen ajatellaan kertautuvan oktaaveittain ylös- ja alaspäin. Kansanmusiikintutkijat ovat katsoneet tähän ideaan perustuvien, vertailukelpoisella tavalla kirjoitettujen asteikkojen sopivan luokitteluun erinomaisesti. Yleisimpiä asteikkotyyppien luokitteluperusteita on asteikon 1. ja 3. asteen välinen intervalli. Sen avulla skaalat voidaan jakaa duuri- ja molliluokkiin (ks. Cazden 1971, 69). Tämä erottelu on ollut luonnollinen ratkaisu länsimaisen duurimollijärjestelmän sisäistäneille tutkijoille.

Vielä vuosisadan alkupuolella tutkijat pitivät diatonista asteikkoa sävelasteikon yleispätevänä mallina ja päämääränä, johon asteikkojen historiallinen kehitys pyrki. Siksi pentatoniset ja niitäkin suppeammat asteikot tulkittiin vajaiksi diatonisiksi skaaloiksi. (Ks. Oramo 1978, 355.) Duurin ja mollin perustavanlaatuisuus oli vallitseva paradigma kaikessa länsimaisessa musiikin-

2 Amerikankreikkalainen Sotirios Chianis $(1980,678)$ esittää asian seuraavasti: 'The term 'mode' in Greek folk music should not be interpreted as meaning simply a succession of different pitches within a given ambit, having a given intervallic structure. It implies the occurrence of certain melodic formulae before, after and between given essential skeletal melodic notes. Furthermore, because of their importance in both vocal and instrumental forms, steretyped (melodic) cadential formulae must be included in the definition". 
tutkimuksessa. Ilmari Krohnin ajatuksia säveljärjestelmien kehityksestä ja luonteesta voi pitää varsin tyypillisinä. Matti Huttusen $(1993,97)$ mukaan Krohn omaksui Hugo Riemannilta käsityksen, että '"kaikkien aikojen ja kansojen musiikissa sävellajeja on vain kaksi: duuri ja molli". Kaikki muut asteikot olivat siis duurin ja mollin muunnoksia. Krohn piti kaikkien kulttuurien säveljärjestelmiä pohjimmiltaan samanlaisina kuin duurimollitonaalisuutta. Tämä ajatus mielessään hän perehtyi antiikin tetrakordijärjestelmiä ja kiinalaisen musiikin perussäveliä koskevaan kirjallisuuteen.

Monet Balkanin musiikin tutkijat ovat kiinnittäneet huomiota duuri- ja molliterssin lisäksi siihen, rakentuuko asteikko diatonisista vaiko kromaattisista sävelryhmistä (ks. esim. Michaelis 1954, 269; Ciobanu 1969, 385; Džudžev 1970, 274-348). Tämän luokittelujärjestelmän pohjana ovat antiikin Kreikan musiikinteorioiden myöhemmät tulkinnat. Joskus antiikin jäljittely on viety äärimmilleen ideologisista syistä: kreikkalaisen kirkkolaulun uudistaja ja teoreetikko arkkimandriitta Krysanthos (n. 1770-1846) käytti teoriassaan diatonisten ja kromaattisten tetra- ja pentakordien lisäksi myös enharmonista sävelryhmää, koska hän halusi esittää kirkkomusiikin antiikin perillisenä (Zannos 1990, 46-48, 56). ${ }^{3}$ Nykyään kreikkalaisista teoreetikoista ainakin Simonos Karas (1989) jatkaa tätä käytäntöä.

Melodian yleistäminen asteikoksi duuri- ja molliasteikon mallin pohjalta on tavallisin kansanmusiikintutkijoiden tapa saada yksittäisestä melodiasta yleinen asteikko. Tällöin otetaan huomioon ainoastaan sävelkorkeudet ja yksi ainoa sävelfunktio, toonika. Moodin uutta määritelmää käyttäneet tutkijat ovat kehittäneet erilaisia lisäsymboleita kuvaamaan moodin sävelten funktioita ja asteikkona esitetyn moodin melodiaominaisuuksia (ks. esim. Signell 1977, 50-51; Özkan 1984, 73 ja etenkin Zannos 1990, 57). ${ }^{4}$ Monesta osasesta koostuvan yhdistelmämakamin kuvaaminen yhtenä asteikkona on kaikesta huolimatta visaista. Mitä voisikaan yhdistelmämakamin melodian pohjalta laadittu kromaattinen asteikko kertoa makamin rakennekomponenteista ja melodiaominaisuuksista?

${ }^{3}$ Nykykreikkalaista kirkkomusiikkia kutsutaan hyvin usein "'bysanttilaiseksi musiikiksi". Kreikassa "bysanttilaisuutta" käytetään oikeuttamaan kreikkalaiseen kulttuuriin osmanivallan aikana omaksuttuja kulttuuripiirteitä. Monet kreikkalaiset tutkijat ja muusikot pitävät esimerkiksi pitkäkaulaluuttuja bysanttilaisina. Osmanikulttuurin ilmiöitä kutsutaan puolestaan "arabialais-persialaisiksi". Olen luopunut nykykäytössään epähistoriallisesta, ideologisesti värittyneestä ja epämääräisestä bysanttilaisen musiikin käsitteestä vastaavista syistä kuin osmanien taidemusiikin nimittämisestä "turkkilaiseksi klassiseksi musiikiksi"' (vrt. Pennanen 1994b, 50-51, viite 5).

${ }^{4}$ Zannosin sinänsä havainnollisen esitystavan huono puoli on se, että sama symboli merkitsee eri asiaa sijainnista riippuen. 
Balkanin makampohjaisten melodioiden luokittelussa on voitu käyttää samanaikaisesti sekä kirkkosävellajeja että arabien tai osmanien taidemusiikkia käsittelevistä kirjoista otettuja asteikkoja (ks. esim. Kremenliev 1952, 55-73; Džudžev 1970, 247-348; Džimrevski 1985, 50). ${ }^{5}$ Tällöin asteikoiltaan identtiset tai lähekkäiset makamit ovat usein sulautuneet samaksi kirkkosävellajiksi. Melodisilta ominaisuuksiltaan niinkin erilaiset makamit kuin puselik, uşşak, beyati, hüseyniaşiran ja nihavent voidaan luokitella asteikkorakenteen vuoksi aiolisiksi (ks. Reinhard \& Reinhard 1984, 200).

Toisaalta makammelodioille tyypilliset kromaattiset muunnokset on voitu tulkita eri kirkkomoodien ilmentymiksi. Esimerkiksi Džudževin (1970, 276280) "muinaiskreikkalaiseksi dooriseksi moodiksi" eli nykyfryygiseksi nimeämää asteikkoa edustavat kappaleet ovat makam segâh -pohjaisia bulgarialaisia kansanlauluja. Saman kirjoittajan (idem., 297-300) "miksolyydistä eli hyperdoorista moodia" kuvaavat sävelmäesimerkit ovat nekin segâh-pohjaisia. Samaa makamia seuraavien sävelmien jaottelu erilleen johtuu 5. asteesta, joka on edellisessä luokassa puhdas ja jälkimmäisessä vähennetty kvintti. Moodin asteikkomaisuutta painottaessaan Džudžev tulkitsee saman makamin toisistaan poikkeavien melodialiikkeiden tuottamat väliaikaiset muunnokset pysyviksi ominaisuuksiksi.

\section{Tutkittavat makamit}

Segâh, müstear ja hüzzam ovat monista osasista koostuvia yhdistelmämakameja, joiden finalis on segâh-sävel $\left(h^{d}{ }^{l}\right)$. Ne ovat osmanien taidemusiikin makameja, jotka esiintyvät enemmän tai vähemmän muuntuneina myös monissa Balkanin musiikkikulttuureissa. Sävellykset eivät yleensä hyödynnä kaikkia kulloisenkin makamin tarjoamia mahdollisuuksia, joten yhdistelmämakamiin pohjautuva sävelmä voi olla hyvinkin yksinkertainen.

Seuraava makamien esittely perustuu osmaniperinnettä opiskelleen muusikon Jorgos Simeonidisin käsityksiin. Olen hylännyt suuren osan aiemmin käyttämästäni Turkin konservatorioissa opetettavasta Arelin ja Ezgin teoriasta (ks. Pennanen 1994a, 97-98; idem. 1994b, 39-41) ja valinnut uudeksi selitysperustaksi muusikon näkökulman; konservatorioteoria ei mielestäni pysty selittämään soivaa musiikkia tarpeeksi johdonmukaisesti.

${ }^{5}$ Usein käytettyjä lähteitä ovat olleet ainakin Albert Lavignacin toimittaman Encyclopédie de la musique et Dictionnaire de Conservatoire -tietosanakirjan artikkelit (ks. Yekta Bey 1922 ja Rouanet 1922). Lähteisiin on kuulunut myös eurooppalaisille kielille käännettyjä keskiajan arabialaisten teoreetikkojen kirjoituksia, joilla ei välttämättä ole paljoakaan tekemistä oman aikansa eikä etenkään nykyisen arabimusiikin, saati sitten osmaniperinteen esityskäytännön kanssa. 
Makamasteikot syntyvät yhdistelemällä tri-, tetra- ja pentakordeja. ${ }^{6}$ Sävelryhmien liitoskohdalla eli güçlüllä on tärkeä tehtävä melodiassa. Güçlü on useimmiten kvintin tai kvartin päässä finaliksesta, mutta välimatka voi olla myös terssi. Teoreettinen oktaaviasteikko voi laajeta ylös- ja alaspäin perusoktaavin mukaisesti tai siitä poiketen. Kaikki asteikot eivät tosin ulotu oktaaviin saakka. Kuitenkaan makam ei ole pelkkä asteikko. Tämä käy ilmi jo siitä, että osmaniperinteen mukaisesti erinimisiä, asteikoiltaan samanlaisia makameja pidetään erillisinä niiden toisistaan poikkeavien melodiaominaisuuksien vuoksi.

Kuhunkin makamiin kuuluu vakiomotiivisto ja sävelhierarkia. Melodian etenemistä määrää seyir-säännöstö, joka sanelee melodian pysähdyspaikat. Niistä finalis (karar) päättää melodian. Finaliksen yläoktaavilla (tiz durak) on tärkeä asema joissain makameissa. Väliaikaiset pysähdykset (muvakkat kalışlar) eivät tunnu yhtä lopullisilta kuin finalis eivätkä yhtä hallitsevilta kuin güçlü. Sisääntulo (giriş) on sävel, joka korostuu melodian ensimmäisessä säkeessä, ja se voi olla makamin melodisesta suunnasta riippuen finalis, güçlü tai finaliksen yläoktaavi. Kunkin makamin seyirillä on melodinen suunta, joka määritellään sisääntulosävelen pohjalta. Suunta on nouseva, mikäli melodia alkaa finaliksesta, laskeva, mikäli se alkaa finaliksen yläoktaavista ja nousevalaskeva, mikäli se alkaa güçlüstä. (Vrt. Signell 1977, 48-51; Chabrier 1991, 101.)

Makam segâhin asteikon alaosassa on finalikselta eli segâh-säveleltä (hdl) alkava segâh-trikordi (esim. 1a). Sävelet kürdî ( $\left.\mathrm{a}^{1}\right)$ ja rast $\left(\mathrm{g}^{1}\right)$ esiintyvät usein finaliksen alapuolella. Segâh-trikordi kohtaa asteikon yläosan sävelellä $\mathrm{d}^{2}$ (neva), joka on siis makamin güçlü. Yleisin yläosa on $\mathrm{d}^{2}$-sävelelle transponoitu rast-tetrakordi (esim. 1b). Samalle sävelelle transponoitu buselik-tetrakordi on niin ikään mahdollinen (esim. 1c). ${ }^{7}$ Näiden tetrakordien vaihtoehtoisuus tulee ilmi alaspäisissä melodiakuluissa, joissa esiintyy joko rastin $\mathbb{f}^{2}$ (eviç) tai buselikin $\mathrm{f}^{2}$ (acem). Käytännössä rast-tetrakordin intonaatio poikkeaa teoreettisesta: $e^{d^{2}-s a ̈ v e l ~ s o i t e t a a n ~ v a i n ~ a l a s p a ̈ i n ~ m e n n e s s a ̈ a ̈ n . ~ Y l o ̈ s p a ̈ i s i s s a ̈ ~ k u l u i s s a ~ s e n ~ s i j a l l a ~}$ on $\mathrm{e}^{2}$. Tetrakordien päälle voidaan lisätä vielä segâh-trikordin alaspäisen laajennuksen oktaavikerrannainen (esim. 1d).

Segâhin perusasteikkoa voidaan muunnella monin tavoin. Eviç-sävelelle $\left(f^{* 2}\right)$ transponoitu segâh-asteikko alaspäisine laajennuksineen esiintyy usein segâh-sävelmissä (esim. 1e). Näin eviç-sävelestä tulee väliaikainen pysähdys, melodian tilapäinen keskus. Perusasteikon korotettu 2. aste voidaan tulkita melodialiikkeestä riippuen joko güçlün johtosäveleksi tai segâh-trikordin korvautumiseksi müstear-trikordilla (esim. 1f). Säveleltä g ${ }^{1}$ (rast) alkava rast-pen-

\footnotetext{
6 Virallinen turkkilainen teorian tuntee vain tetra- ja pentakordeja. Sen sijaan arabialainen teoria tunnustaa myös trikordit ja käyttää niitä makam-asteikkoja muodostaessaan (ks. Chabrier 1991, 101).

7 Oppikirjojen mukaan makam segâhin asteikon perusmuoto koostuu segâh-pentakordista ja eviç-sävelelle (f $\|^{2}$ ) transponoidusta hicaz-tetrakordista (ks. Özkan 1984, 276).
} 
takordi tasoittaa segâhin johtosävelen $\mathrm{a}^{1}: \mathrm{ksi}(\mathrm{esim} .1 \mathrm{~g})^{8}$. Tällöin sävel rast muuttuu rast-jakson - muttei kuitenkaan koko teoksen - finalikseksi. Vaikka segâh-melodia voi koostua monenlaisista aineksista, lyhytaikaisia poikkeamia perusasteikosta ei pidetä modulaatioina. Makamin finalis segâh $\left(h d^{l}\right)$ on samalla sisääntulosävel, joten makamin melodinen suunta on nouseva.

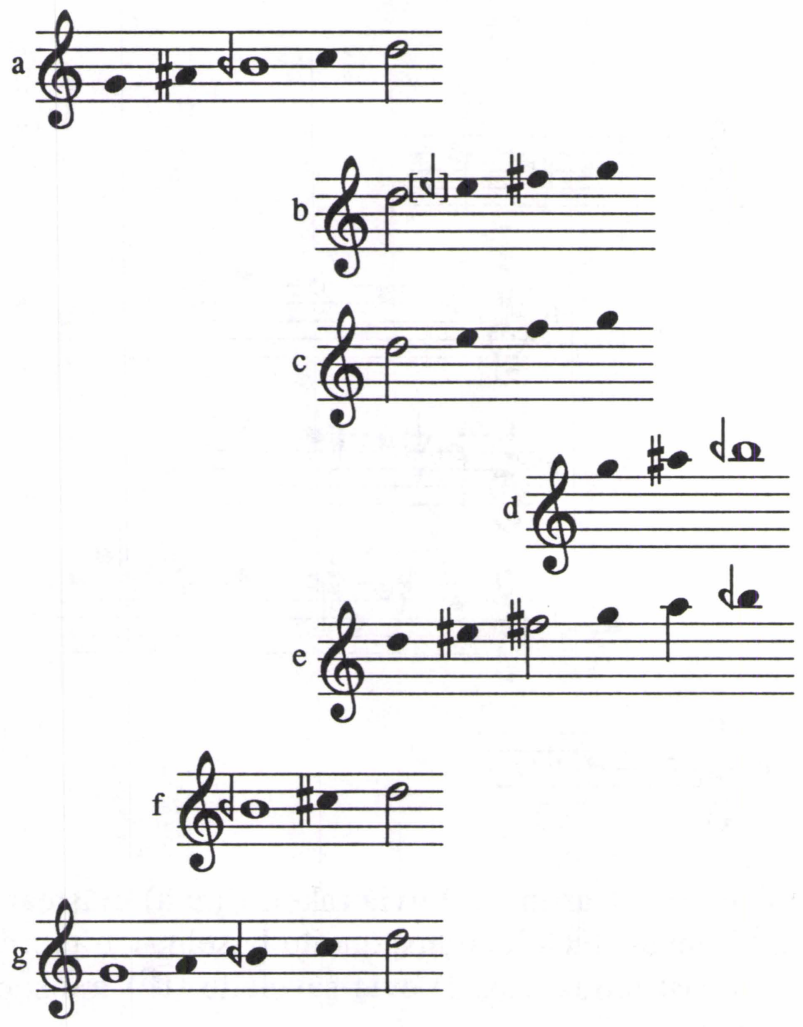

Esimerkki 1. Makam segâhiin sisältyviä rakenteita: a) segâh-trikordi alaspäisine laajennuksineen, b) neva-sävelelle $\left(\mathrm{d}^{2}\right)$ transponoitu -tetrakordi, c) neva-sävelelle $\left(d^{2}\right)$ transponoitu buselik-tetrakordi, d) segâh-trikordin alaspäisen laajennuksen oktaavikerrannainen, e) eviç-sävelelle ( $\left(\mathbb{f}^{2}\right)$ transponoitu segâh-asteikko, $f$ ) müsteartrikordi ja g) rast-pentakordi.

${ }^{8}$ Signell $(1977,129-130)$ pitää finaliksen, johtosävelen ał1 ja $^{1}{ }^{1}$-sävelen intervallisuhteita tärkeänä segâh-kappaleen tuntomerkkinä. Silti johtosävel voi korvautua $\mathrm{a}^{1}$-sävelellä makamin luonteenpiirteiden katoamatta. Segâh-melodian ei myöskään tarvitse välttämättä käydä finaliksen alapuolella. 
Makam müstear on makam segâhin lähisukulainen. Sen perusasteikko rakennetaan yhdistämällä müstear-trikordi (esim. 2a) ja neva-sävelelle $\left(\mathrm{d}^{2}\right)$ transponoitu buselik-tetrakordi (esim. 2b). Myös rast-tetrakordi on mahdollinen (esim. 2c). Finaliksen johtosävel on a $\sharp^{1}$. Makam segâhin tavoin makam müstear -sävelmä sisältää usein motiiveja, jotka juontuvat eviç-sävelelle $\left(\mathrm{f}^{2}\right)$ transponoituun segâh-asteikkoon (esim. 2d). Alaspäisissä kuluissa müstear-trikordi voi korvautua segâh-trikordilla (esim. 2e). Müstearin melodinen suunta on nouseva.

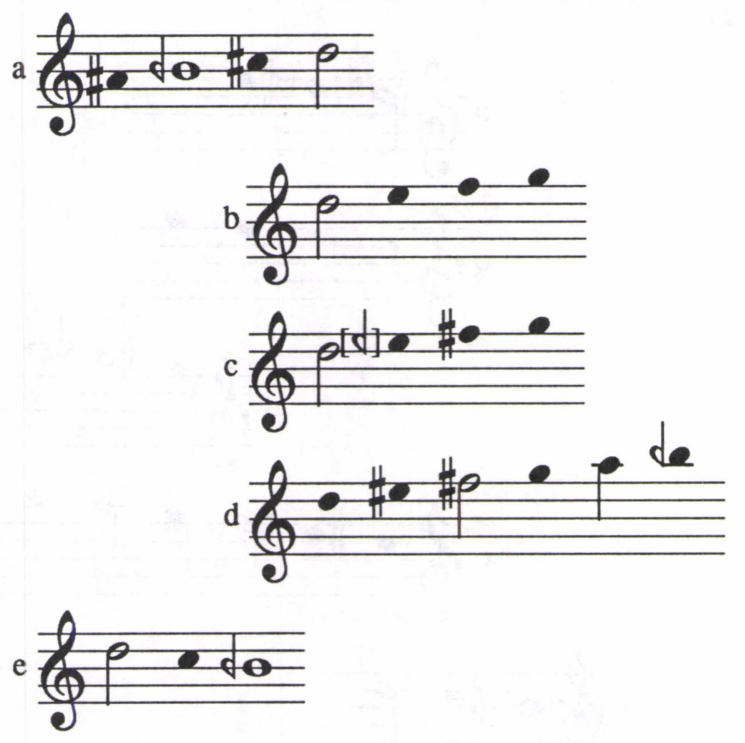

Esimerkki 2. Makam müsteariin sisältyviä rakenteita: a) müstear-trikordi ja finaliksen johtosävel, b) neva-sävelelle transponoitu buselik-tetrakordi, c) b) neva-sävelelle transponoitu rast-tetrakordi, d) eviç-sävelelle ( $\left.f^{\left.\right|^{2}}\right)$ transponoitu segâh-asteikko sekä e) segâh-trikordi.

Makam hüzzamin perusmuoto koostuu segâh-trikordista (esim 3a) ja nevasävelelle $\left(\mathrm{d}^{2}\right)$ transponoidusta hicaz-tetrakordista (esim. 3b). ${ }^{9}$ Muusikoiden käyttämässä intonaatiossa tetrakordin $e^{2}$ ei ole niin matala eikä $\mathrm{f}^{2}$ niin korkea kuin teoriassa. Usein tetrakordi laajenee hümayun-asteikoksi (esim. 3c). Melodiaa värittää güçlün $\left(d^{2}\right)$ johtosävel $c \sharp^{2}$. Finaliksen johtosävel on $a^{1}$. Melodinen

\footnotetext{
${ }^{9}$ Virallisen teorian mukaan makam hüzzamin perusmuoto koostuu hüzzam-pentakordista ja eviç-sävelelle (f ${ }^{2}$ ) transponoidusta hicaz-tetrakordista (ks. Özkan 1984, 288). Nykyteoriaa monissa kohdin kritisoiva Zannos $(1990,57)$ hyväksyy hieman yllättäen tämän erheellisen selity smallin. Lisäksi hän pitää rastia $\left(\mathrm{g}^{\mathrm{l}}\right)$ makam hüzzamille tärkeänä sävelenä, mikä ei pidä paikkaansa, koska makam painottaa güçlün yläpuolista aluetta.
} 
suunta voi olla joko nouseva tai nouseva-laskeva, joten sisääntulosävel on finalis tai güçlü. Hüzzam-melodiat liikkuvat güçlün yläpuolisella alueella useammin kuin segâh-melodiat, joilla on taipumus painottaa finalista ja sen alapuolisia säveliä (vrt. Signell 1977, 75).

a

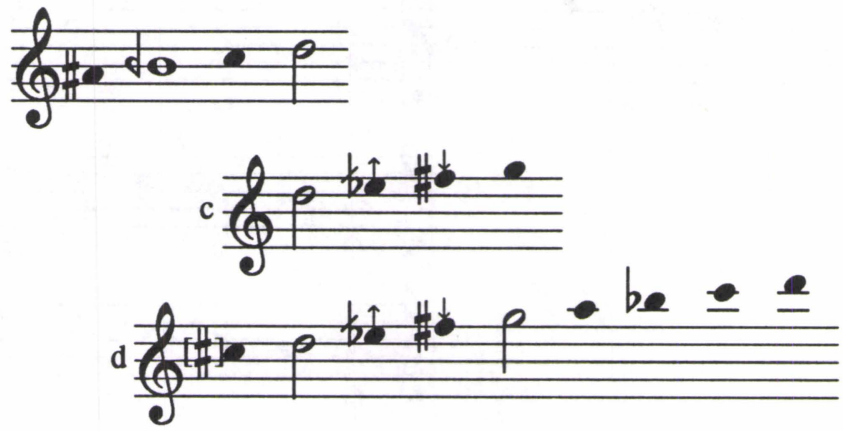

Esimerkki 3. Makam hüzzamiin sisältyviä rakenteita: a) segâh-trikordi ja finaliksen johtosävel, b) neva-sävelelle transponoitu hümayun-tetrakordi sekä c) neva-sävelelle transponoitu hümayun-asteikko.

\section{Balkanilaistuneet makamit ja niiden muunnosmuodot}

Makamit segâh ja hüzzam sekä joskus myös müstear esiintyvät Balkanin maaseutu-, kaupunki- ja uskonnollisessa musiikissa alkuperäismuodoissaan, joskin nykyään usein tasavireiseen järjestelmään mukautettuina. ${ }^{10}$ Segâhilla ja müstearilla on lisäksi muunnosmuoto. Tämän tutkielman balkanilaistuneet makamit eivät useinkaan noudata mitään seyiriä.

Mikäli alkuperäismakameja noudattaviin sävelmiin on liitetty harmonia, soinnutusratkaisu on länsimaisen teorian kannalta erikoinen: I asteen soinnun pohjasävel on suurta terssiä makamien alkuperäistä finalista alempana. Finalis sattuu siis I asteen duurisoinnun terssille. (Esim. 4a, 4b.) Tämä mahdollistaa funktionaalisen sointusuhteen I-V käytön (ks. Pennanen 1994a, 99). Makam segâhin ja makam müstearin muunnosmuodon tärkeät sävelet sijoittuvat $\mathrm{h}^{1}$ - ja $\mathrm{d}^{1}$-sävelille, mutta alkuperäismakamista poiketen finalis on suurta terssiä alempana sävelellä $\mathrm{g}^{1}$ (vrt. Suliţeanu 1976, 58). Muutos johtuu sointujen lisäämises-

${ }^{10}$ Makam segâhin lähin vastine kreikkalaisessa kirkkolaulussa on legetos, hüzzamin taas toinen ekhos (Zannos 1990, 51). Ainakin asteikon tasolla myös serbialaisessa kirkkolaulussa on vastaavanlaisia moodeja (ks. Žganec 1956, 355, 359). Makam segâh Sarajevon dervissien hymnissä, ks. Pennanen 1992, 225-233. 
tä; I asteen soinnun pohjasävel on vetänyt finaliksen puoleensa. Toisen oktaavin alku ei kertaa ensimmäisen oktaavin säveliä, joten oktaavit ovat epäsymmetrisiä (esim. 4c, 4d). Makam hüzzamista ei ole syntynyt vastaavanlaista muunnosta luultavasti siksi, ettei makam suosi finaliksen alapuolista aluetta.

a
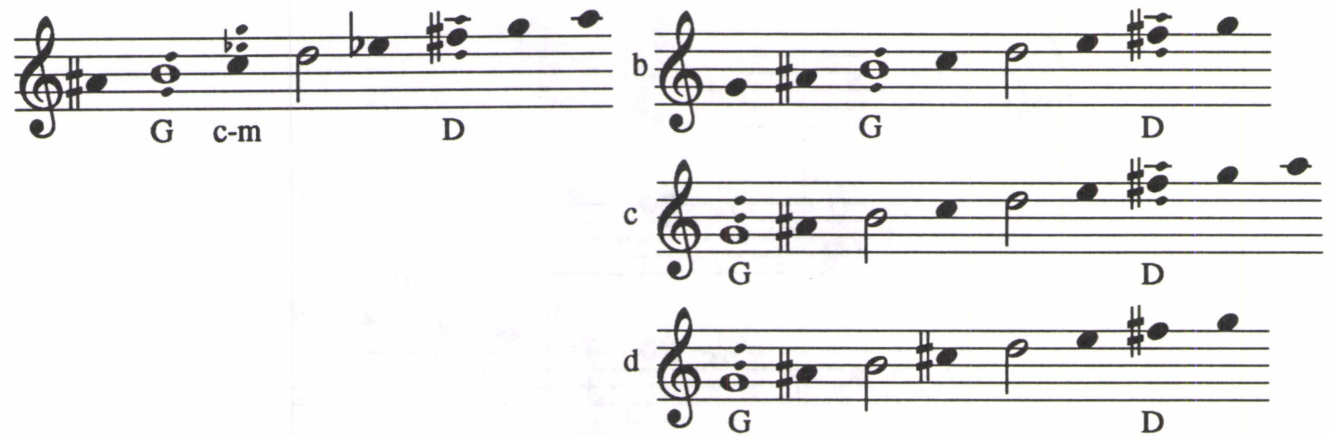

Esimerkki 4. a) Tasavireisen hüzzamin ja b) tasavireisen segâhin perusmuodot sekä c) segâhin ja d) müstearin muunnosmuodot asteikkoina tärkeimpien sointujen kera.

Nämä kolme makamia ja niiden muunnokset ovat yleisiä etenkin kreikkalaisessa kaupunkimusiikissa, rebetikassa. Rebetika-muusikot kutsuvat käyttämiään moodeja nimellä dromos. Koska rebetikassa ei ole yhteistä kodifioitua ja eksplikoitua musiikinteoriaa, dromosien nimitykset sekä käsitykset niiden rakenteesta ja ominaisuuksista vaihtelevat muusikon taustasta ja iästä riippuen. Voi tuntua hieman hämmentävältä, että yleensä muusikot kutsuvat käyttämäänsä makam segâhin vastinetta dromos huzamiksi ja makam hüzzamin vastinetta dromos segahiksi. He eivät tunne eivätkä käytä nimitystä "müstear", vaikka tuon makamin piirteitä esiintyy sävelmissä. Rebetikan etnoteoriassa müstear on sulautunut dromos huzamiin, siis makam segâhiin. Omassa tutkimuksessani olen nimennyt dromos huzamin suoraan makam segâhista kehittyneen muodon "dromos huzam A:ksi" (esim. 4b) ja sen soinnutuksen vuoksi muuttuneen muodon "dromos huzam B:ksi" (esim. 4c). Tämän tutkimuksen kiinnostavin dromos on huzam A:n diatoninen muoto, joka ei ulotu finaliksen alapuolelle.

Näiden kolmen makamin kreikkalaismuotojen kehityksen ja ominaisuuksien tutkimus on ollut vähäistä. Tämä johtunee analyysin poikkeuksellisesta mutkikkuudesta, sillä soinnutuksen ja moniäänisyyden tuomat muutokset hankaloittavat alkuperäismakamien tunnistamista. Jotkut tutkijat eivät ole ennakkokäsitystensä vuoksi yrittäneetkään etsiä rebetikasta makam segâhin ja hüzzamin johdannaisia. Esimerkiksi Peter Manuel $(1989,78,83)$ ei ota huomioon mahdollisuutta muuttaa makammelodioiden mikrointervalleja tasavireisiksi. Hän väittää makam rastiin, beyatiin, hüzzamiin, segâhiin ja sabâan pohjautuvien moodien harvinaistuneen rebetikassa sointujen yleistymisen myötä, koska näiden makamien neutraalit inter- 
vallit ja asteikkojen kromaattisuus hylkivät kolmisointuharmoniaa. ${ }^{11}$ Oma analyysini on päätynyt täysin päinvastaiseen lopputulokseen: makam segâh eli siitä kehittyneet molemmat dromos huzam -tyypit sekä makam hüzzam ja siihen perustuva dromos segah olivat yleisiä ennen toista maailmansotaa edeltäneessä rebetikassa, ja dromos huzam A:n yksinkertaistettu muotoa käytettiin runsaasti sodan jälkeen (ks. Pennanen 1994b, 47-49).

\section{Toonika ja finalis duurimollijärjestelmässä}

Sointusäesteisten hüzzam-, müstear- ja segâh-sävelmien analyysiongelmien perussyy niin tutkijoiden kuin muusikoidenkin keskuudessa liittyy oman tulkintani mukaan finaliksen ja toonikan käsitteisiin. Finalis on modaalisen melodian päätössävel. Toonika on puolestaan duurimollijärjestelmässä sävellajin perussävel, jonka mukaan sävellaji nimetään. Samalla se on perussävelle rakentuvan sointuasteen nimitys. Melodia päättyy tavallisesti toonikasäveleen.

Yleensä länsimaisessa musiikkikulttuurissa hyväksytään finaliksen ja toonikan yhtäläisyys. Monet kansanmusiikin, ulkoeurooppalaisen musiikin ja varhaisen länsimaisen polyfonian tutkijat ovat vasta äskettäin huomanneet tämän käsityksen olevan ennemminkin kulttuurisidonnainen olettamus kuin musiikin luontainen ominaisuus.

Länsimaisen tonaalisen musiikin teoriassa oikeastaan vain toonikasointua pohjamuodossaan pidetään tyydyttävänä sävelmän päätössointuna. Toonikalopuketta sanotaan täydelliseksi, mikäli viimeinen toonikasointu on vahvalla tahtiosalla, pohjamuodossa ja oktaaviasemassa (Salmenhaara 1970, 234). Oktaaviaseman ohella toonikasointu voi olla myös terssi- tai kvinttiasemassa. Tällöin kadenssi on epätäydellinen. Mikäli toonikasointu on käännetty, säe luultavasti jatkuu niin, että varsinainen kadenssi seuraa vasta myöhemmin (esim. 5). Terssi sopraanossa ei ole sävyltään niin selvästi lopettava kuin toonikasävel ääriäänissä. (Idem., 44; Piston 1950, 127.)

Täydellisen kadenssin itsestään selvä asema sävellyksen lopussa 1700-luvulla käy ilmi Jean-Philippe Rameaun (1971 [1722], 160) kannanotosta: "Voimme päättää musiikkikappaleen ainoastaan täydelliseen kadenssiin moodin pääsävelelle; muuhun ei sielu tyydy. Kuinka järjetöntä on ehdottaa moodeja, jotka eivät mukaudu näihin vaatimuksiin!" Taidemusiikkia lukuun ottamat-

11 On epäselvää, mitä Manuel tarkoittaa neutraaleilla intervalleilla mainitsemissaan makameissa. Mahdollisesti hän arvelee samannimisten arabialaisten ja osmanimakamien vastaavan rakenteeltaan toisiaan, mikä ei yleensä pidä paikkaansa (ks. Powers 1980, 424-425; Chabrier 1991, 99, 103). 
ta asiantila ei ole muuttunut merkittävästi sitten 1700-luvun. Valtaosa esimerkiksi nykyisen länsimaisen populaarimusiikin kadensseista tyydyttäisi Rameauta.

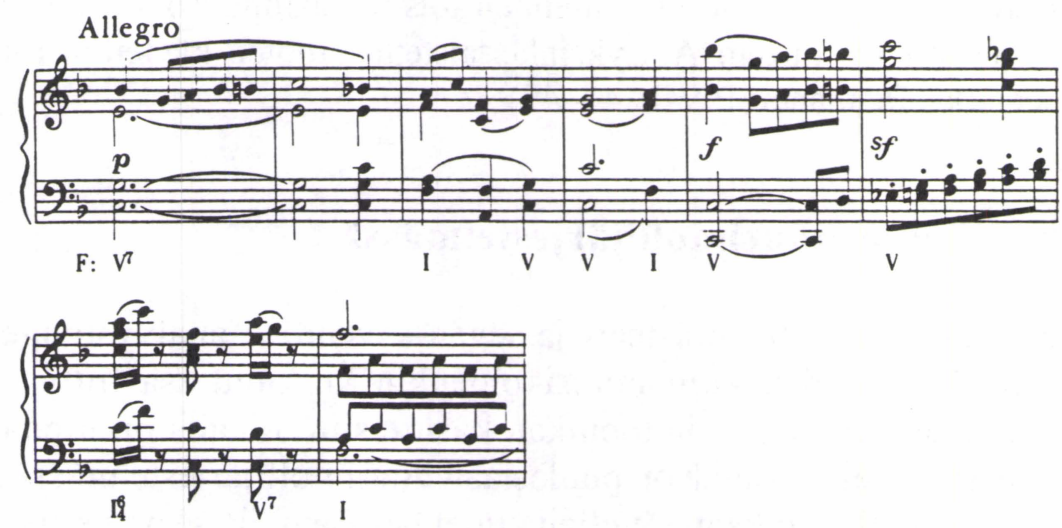

Esimerkki 5. Ote Beethovenin 8. sinfoniasta (Piston 1950, 128).

Paperilla diatoninen dromos huzam A, joka ei käy finaliksen alapuolella, näyttää fryygiseltä asteikolta, mutta sen perussointu on finalista terssin alempi duuri. Myös dromos segahin kolmas aste on pieni terssi, mutta dromos soinnutetaan duurin avulla. Nämä moodit noudattavat Rameaun torjumaa periaatetta; niiden asteikkojen finalis on toonikasoinnun terssissä. Länsimaisen sointuteorian näkökulmasta huzam $\mathrm{A}: \mathrm{n}$ ja segahin kadenssit ovat siis epätäydellisiä. Nämä dromosit tarjoavat toisenkin länsimaisen musiikkikulttuurin kannalta visaisen pähkinän: kuinka asteikon 3. aste voi olla pienen terssin päässä finaliksesta samalla kun toonikasointu on duuri?

\section{Vajaa duuriasteikko}

Yhtä lailla tutkijoiden kuin muusikoidenkin suosima diatonisen huzam A:n tulkinta on 3. asteelle päättyvä duuri (ks. esim. Lambelet 1934, 109-110; Kutsothanasis 1990, 38-39). Periaatteessa tämä analyysimalli sallii sävelmän päättymisen mille tahansa sävellajin toonikasoinnun kolmesta sävelestä. Tosin rebetikan dromoseista kaikki paitsi huzam A ja segah päättyvät 1. asteelle. Teoriassa moodilla ei ole yhtä vakituista finalista, vaan sävellajin toonika määrää asteikon.

Analyysimallia pisimmälle pohtinut tutkija lienee Béla Bartók. Hän kirjoittaa löytäneensä hertsegovinalaisesta materiaalista duuriasteikon, joka päättyy 3. asteelle. Hänen mielestään tämä asteikko esiintyy lähinnä länsimaisperäisissä sävelmissä. (Bartók \& Lord 1978 [1951], 61.) Bartókin arvelu osuu harhaan, koska sävelmät ja niistä saatu asteikko täyttävät makam segâhin tunnusmerkit. 
Bartók oli aikansa lapsi, joten hän tulkitsi kaikki skaalat duuri-ja molliasteikon kautta. Ilmeisesti hän tosiaankin kuuli makam segâh -sävelmät duureina. (Vrt. Oramo 1978, 352-354.)

Bartók transponoi sävelmänsä siten, että kaikkien finalis on $\mathrm{g}^{1}$. Hän selittää paperilla samoilta näyttävien "erikoisen duuriasteikon" ja fryygisen asteikon eroiksi skaalojen pääsävelet: edellisessä ne ovat $e b^{1}-\mathrm{g}^{1}-\mathrm{b}^{1}-\left(\mathrm{e} \mathrm{b}^{2}\right)$ kun taas jälkimmäisessä $\left(d^{1}\right)-g^{1}-b^{1}-d^{2}$ (Bartók \& Lord 1978 [1951], 61). Jää kuitenkin epäselväksi, kuinka analysoiduista sävelmistä kokonaan puuttuvat eb ja eb $b^{2}$ voivat olla pääsäveliä (ks. esim. idem., 151-153). Ongelman ratkaisu on yksinkertainen: Bartók pitää "erikoista skaalaa" vajaana Es-duuriasteikkona (esim. 6).

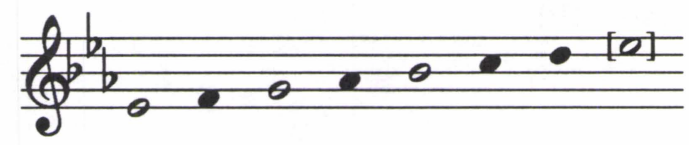

Esimerkki 6. Bartókin "erikoinen duuriasteikko" oman tulkintani mukaan.

Rebetikassa duuritulkinnan loogisuutta lisää se, että mikäli diatoninen dromos huzam A -sävelmä on kaksiääninen, terssin alempana kulkeva harmoniaääni päättyy kuin normaali duurimelodia (esim. 7). ${ }^{12}$ Tulkinta ei juuri vaikuta muusikoiden tapaan toteuttaa diatoninen huzam A edes taksimi-improvisaatiossa. He lopettavat huzam A -sävellykseen liittyvän taksimin huzamin finalikseen, koska se on myös sävellyksen finalis. Analyyseja tehdessään muusikot toimivat toisin kuin Bartók. He eivät transponoi diatonisen huzam A:n finalista muiden dromosien finalisten tasolle. Rebetikan etnoteoriassa buzukin ylin eli $\mathrm{d}^{\mathrm{l}}$-kielikuoro on analyysin apuväline, joka ohjaa muusikon ajattelua. Etnoteorian kiinteä yhteys käytännön musisointiin estää poikkeavien finalisten transponoinnin. Sen sijaan muusikot lisäävät toonikasoinnun pohjasävelelle rakentuvaan asteikkoon perussävelen ja toisen asteen.

Rebetika-muusikoiden duuriin päätyvät diatonisen huzam A:n analyysit ilmentävät modernisaatiota, musiikkikulttuurin tai sen osien satunnaista liukumista länsimaisen musiikin ja musiikkielämän suuntaan niin, etteivät länsimaisista poikkeavien peruspiirteet juuri muutu (ks. Nettl 1985, 20).

\footnotetext{
12 Joidenkin ateenalaismuusikoiden analyysit diatonisen huzam A:n esimerkkinä käyttämästäni kappaleesta Varka jalo (ks. Pennanen 1994b, 47-49) ovat kuvaavia. Vuoden 1994 heinäkuussa haastattelemani länsimaisen musiikkikoulutuksen saanut rebetika-sävelmien nuotintaja ja sovittaja Jorgos Theofilopulos vastasi kysymykseeni Varka jalon dromosista: "Tietysti duuri! Eikö tämä nuorimies tunne musiikinteoriaa?"
} 

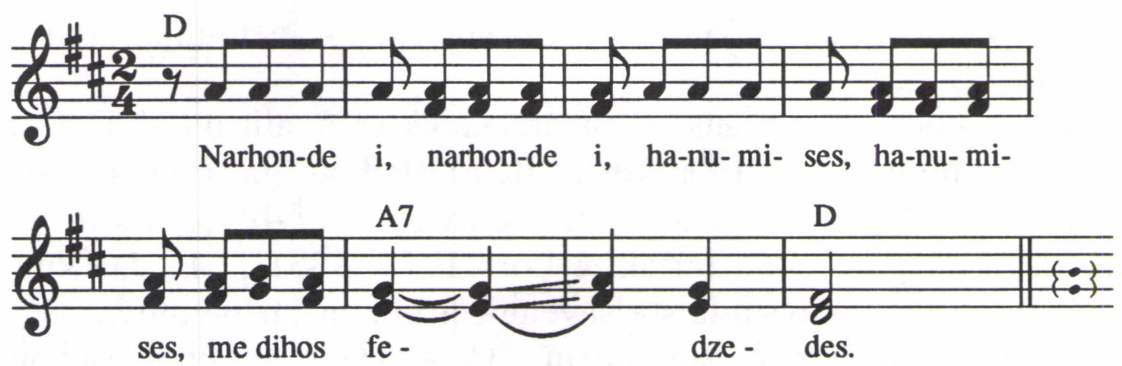

Esimerkki 7. Ote Jannis Papaioannun sävellyksestä O bufedzis vuodelta 1948 (EMI 14C 13471296, A8). Melodian ja harmoniaäänten oktaavikerrannaiset on jätetty kirjoittamatta. Nuotinnos RPP.

\section{Toonika finaliksena}

Vajaan duuriasteikon idea ei sovellu sellaisenaan huzam A -sävelmiin, joissa esiintyy duuriasteikkoon kuulumaton finaliksen johtosävel. Siksi asteikkoesitykset eivät kelpuuta dromos huzam A:n tätä muotoa. Sen sijalla on joka länsimaiseen asteikkokäsitykseen sopiva huzam B, jonka finalis on samalla toonikasoinnun pohjasävel. Tämä dromos voidaan johtaa rebetika-repertoaarista (ks. Pennanen 1994a, 100). Johtosävelen sisältävien huzam A -sävelmien katsotaan sisältyvän tähän dromosiin vastaavista syistä kuin johtosävelettömien huzam A -kappaleiden duuriin.

Dromos segahin kohdalla analyysimalli johtaa tilanteeseen, jossa segah-sävelmillä ja niitä selittämään luodulla teoreettisella asteikolla on vähän tekemistä toistensa kanssa. Kutsothanasisin $(1989,30)$ ja Pajatisin $(1992,41)$ dromos segah -asteikko alkaa toonikasoinnun eli D-duurin pohjasävelestä (esim. 8).

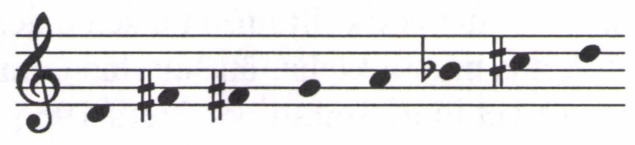

Esimerkki 8. Kutsothanasisin $(1989,30)$ ja Pajatisin $(1992,41)$ dromos segah -asteikko.

Molemmat kirjoittajat havainnollistavat asteikkoa esimerkkisävelmän avulla. Kutsothanasisin sävelmän finalis on $\mathbb{f}^{\sharp 1}$, kuten aina dromos segahissa. Koska finalis voi sijaita sävellajin toonikasoinnun jossain sävelessä, tässäkin tapauksessa esityskäytännön mukaisen segah-kappaleet sisältyvät länsimaisen periaatteen mukaan laadittuun asteikkoon. Pajatis on puolestaan säveltänyt taksi- 
mi-improvisaation kaltaisen mallimelodian, jonka finalis on $\mathrm{d}^{1}$ (esim. 9). Perinnettä seuraava muusikko ei lopettaisi taksimiaan näin. Pajatis on omaksunut länsimaisen toonikafinaliksen ohella myös oktaavisymmetrian idean, sillä sävelletyn taksimin toisen oktaavin sävelet ovat perusoktaavin kerrannaisia.

Myös dromos-kappaleiden soinnutusmallit ovat usein kaukana perinteestä. Bukuvalas $(1991,97)$ rakentaa asteikkoihinsa sointuja jokaiselle sävelasteelle, kuten länsimaisessa teoriassa. Tuloksena ei ole aina tyylinmukaisia eikä edes käyttökelpoisia kolmisointuja. Bukuvalas on laatinut esimerkin 10 dromos segah -asteikkoon varsin erikoisia sointurakenteita. Asteikko on sama kuin Kutsothanasisilla ja Pajatisilla.

Dromos- ja buzukioppaiden kirjoittajat ovat nojautuneet niin vahvasti länsimaiseen musiikinteoriaan, ettei enää voi puhua modernisaatiosta. Asteikkojen rakentaminen länsimaisen ajattelun pohjalta ja säveltäminen niihin on jo länsimaistumista, keskeisten länsimaisista poikkeavien puolien korvautumista länsimaisilla siten, että perinteen perusta muuttuu (ks. Nettl 1985, 20).
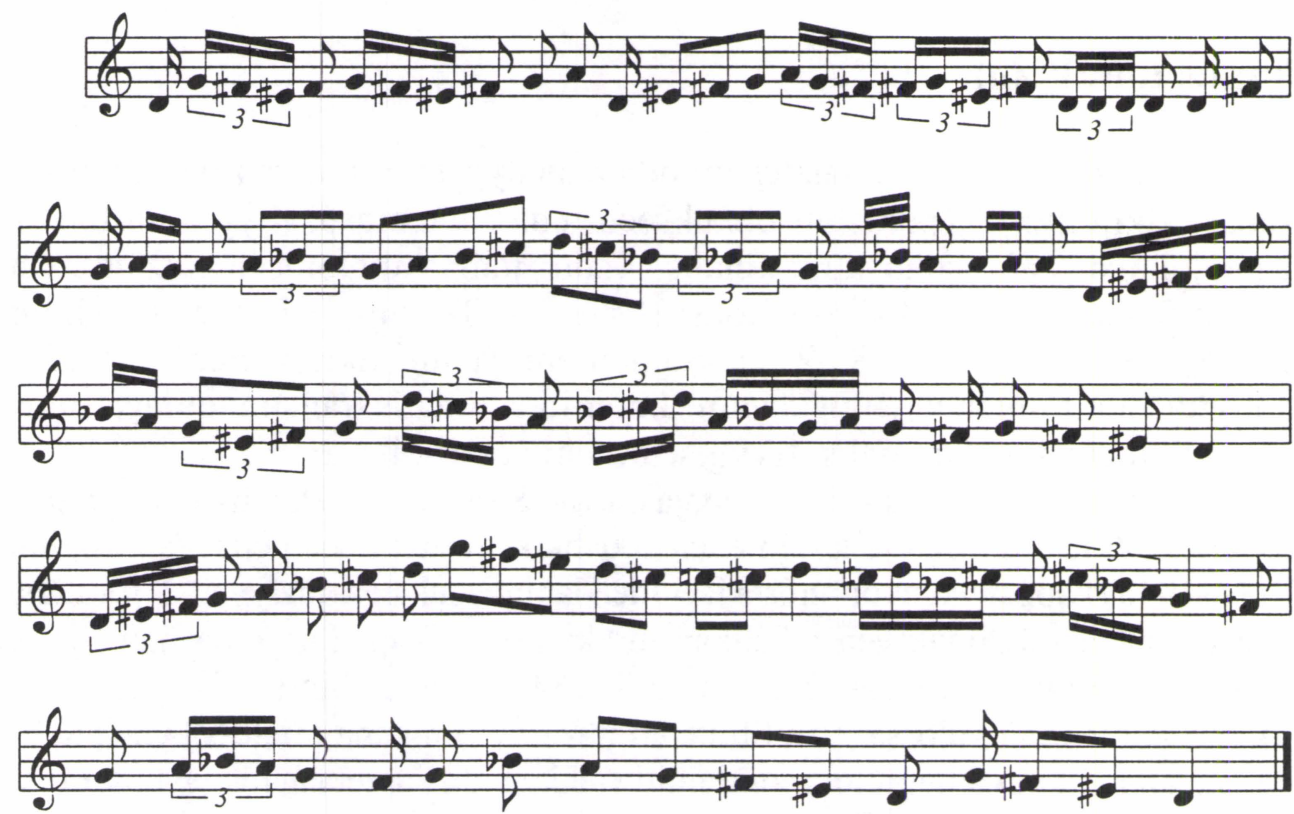

Esimerkki 9. Pajatisin $(1992,43)$ taksimi-improvisaation kaltainen dromos segah -sävellys. 


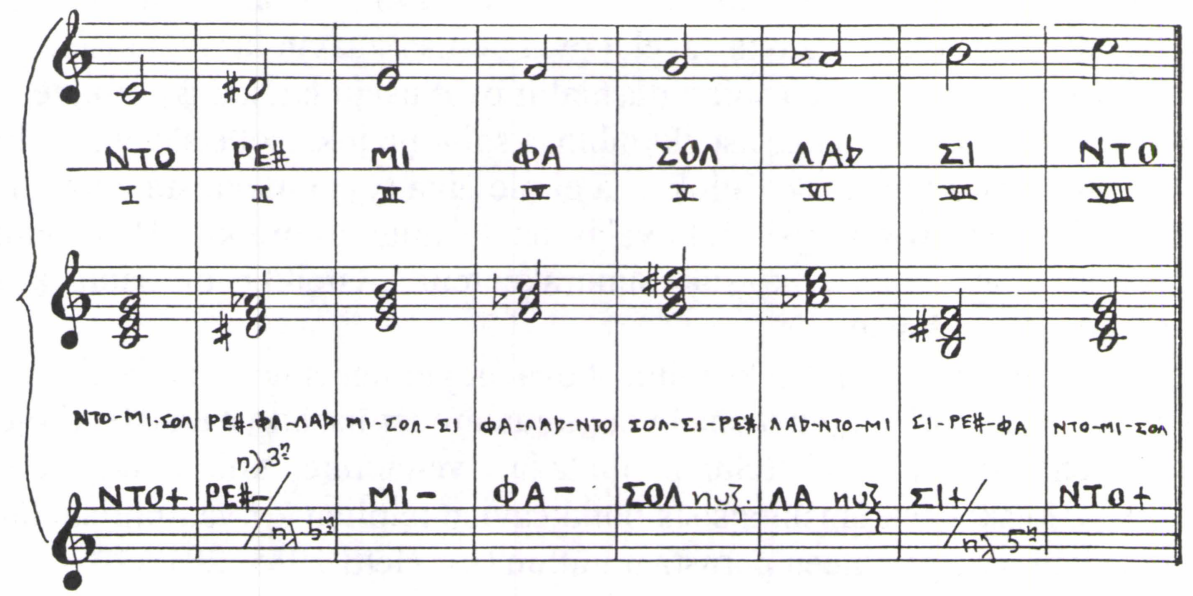

Esimerkki 10. Bukuvalasin $(1991,97)$ esittämä dromos segah -asteikko sointuineen.

\section{Finalis toonikana}

Toinen balkanin segâh-pohjaisten moodien analyysimalli on ominainen ainoastaan tutkijoille. Se perustuu oletukseen, että sävelmä päättyy aina toonikaan, joka on siis sama kuin finalis. Tämä johtaa diatonisen huzam A:n tulkitsemiseen fryygiseksi asteikoksi (ks. esim. Trærup 1970, 45, sävelmät 12, 45, 63; Frye 1973, 8, 232). Soinnutetussa musiikissa tämä ratkaisu edellyttää harmonian jättämistä vaille huomiota. Finalis transponoidaan suuri terssi alkuperäistä alemmaksi fryygisen toonikan tasolle.

Analyysimallin kiinnostavin soveltaja on van Straten (1989), jonka pro gradua vastaava tutkielma sisältää kymmenen rebetika-säveltäjä Vangelis Papazoglun (1897-1943) kappaleen nuotinnosta ja niiden lauluosuuksien analyysit. Kirjoittaja on valinnut lähtökohdakseen rebetikan turkkilaisen alkuperän, joten hän pyrkii analysoimaan nuotinnoksiaan Reinhardin (1984) ja Dietrichin (1987) esittämän turkkilaisen teorian valossa. Van Stratenin näkemys on siinä mielessä yksipuolinen, ettei hän kiinnitä huomiota sointuihin vaikka niitä käytetään hänen tutkimusmateriaalissaan, Vangelis Papazoglun sävellysten ensilevytyksillä. Yleensäkin hänellä on taipumus kiinnittää enemmän huomiota asteikkoihin kuin melodialiikkeisiin, motiiveihin ja soinnutukseen. Tämän vuoksi hän erehtyy pitämään duurisävyisiä huzam- ja segah-sävelmiä mollipohjaisina.

Van Stratenin $(1989,79)$ haastattelema buzukisti Vasilis Mihailidis kuuluu niihin varsin harvoihin rebetika-muusikoihin, jotka kutsuvat makam hüzzamin kreikkalaista vastinetta dromos huzamiksi. Van Straten on päätynyt Mihailidi- 
sin haastattelun ja soittoesimerkin perusteella käsitykseen, että dromos huzamin eli "chouzamin" asteikko on $d^{1}-\#^{1}-f^{1}-g^{1} / g \#^{1}-a^{1}-b^{1}-c^{2}-d^{2}-e^{2}$ eli lähes sama kuin esimerkissä 8. Van Straten kirjoittaa, että ${ }^{\sharp 1}$ on melodinen dominantti $^{13}$, mutta myös 5 . aste korostuu ja että 4 . aste on korotettu ylöspäisessä melodialiikkeessä ja palautettu alaspäisessä. Lisäksi toisen oktaavin $\mathrm{e}^{2}$ korostuu voimakkaasti. Hän huomauttaa, ettei "chouzamin" toinen oktaavi täsmää ensimmäisen kanssa. Hän on havainnut aivan oikein, että makam hüzzam -asteikko on samanlainen kuin hänen "dromos chouzaminsa", mikäli dromos aloitetaan 3. asteelta.

Tutkija olisi kenties ratkaissut muuntuneiden makamien arvoituksen, mikäli hänen informanttinsa olisi tuntenut dromos segahin, jota useimmat rebetikamuusikot kutsuvat dromos huzamiksi. Mahdollisesti informantti luokittelee omassa etnoteoriassaan tätä dromosta noudattavat sävelmät dromos rastiksi tai dromos madzoreksi, duuriksi. Pahaksi onneksi makam hüzzamista ei ole kehittynyt suuren terssin alkuperäistä finalista alemmaksi päättyvää dromosta. Tämän vuoksi van Straten ei ole löytänyt tutkimusmateriaalistaan yhtäkään sävelmää, josta "dromos chouzam" voitaisiin johtaa.

Analysoidessaan Papazoglun sävellyksen I bambesa lauluosuutta (esim. 11) van Straten muuntaa asteikon d-pohjaiseksi, jolloin se on hänen mukaansa $\mathrm{d}^{1}-\mathrm{e}^{1}{ }^{1}-$ $f^{1}-g b^{1}-a^{1}-b^{1}$ (esim. 12a). Hän siis transponoi sävelmän finaliksen $d: h e n$. Saatu asteikko muistuttaa hänen mielestään dromos sabahia, joskin 2. asteen pitäisi olla suuri sekunti. Hän arvelee, että alkuperäismakamin yhden komman alennettu 2. aste on muuttunut tasavireistettäessä pieneksi sekunniksi. (Van Straten, 86-87).

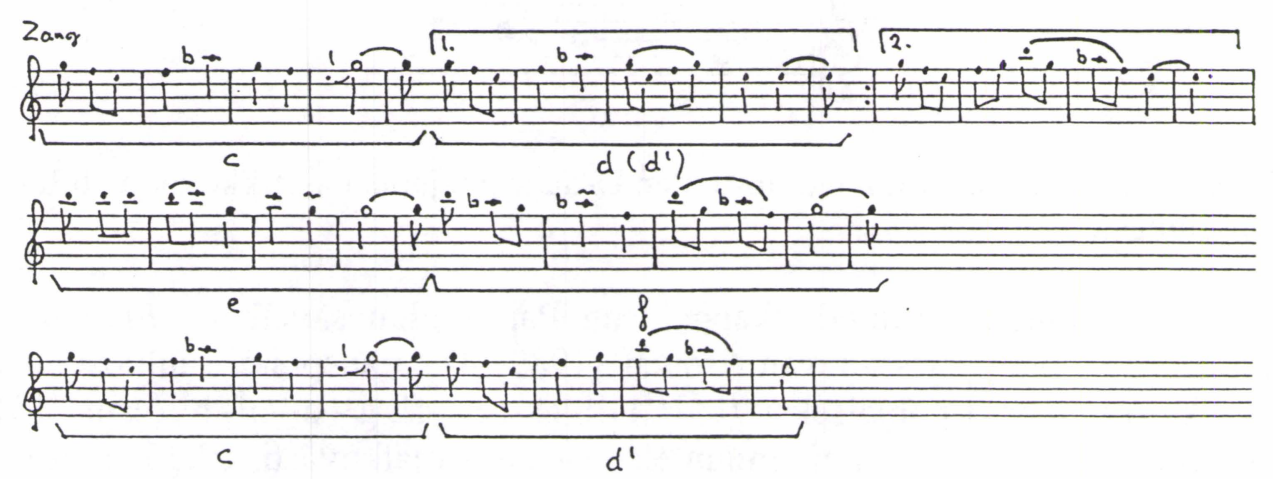

Esimerkki 11. Vangelis Papazoglun sävellyksen I bambesa lauluosuus van Strate$\operatorname{nin}(1989,108)$ nuotintamana.

13 "Melodinen dominantti" (melodische Dominant) on Kurt Reinhardin $(1984,134)$ güçlüstä käyttämä nimitys. 
Van Stratenin analyysimalli on täsmälleen sama kuin se, jolla diatoninen huzam A tulkitaan fryygiseksi asteikoksi. Esimerkin 12b dromos sabahin asteikko muistuttaa hieman van Stratenin I bambesasta saamaa. Erona on 2. aste. ${ }^{14}$ Mikäli kirjoittaja olisi ottanut huomioon myös instrumentaalijohdannon, hän olisi joutunut merkitsemään asteikkoonsa sabahin vastaavasta poikkeavan johtosävelen. I bambesan dromos ei käyttäydy kuin raskasliikkeinen sabah, jonka ydinsolu on esimerkin $12 \mathrm{~b}$ tähdellä $\left({ }^{*}\right)$ merkitty alue finaliksen ja güçlün välimaastossa. Kaiken lisäksi I bambesa on duuripohjainen kappale, kun taas dromos sabah -sävelmä vaatisi mollia. Melodian dromos on kiistatta segah.
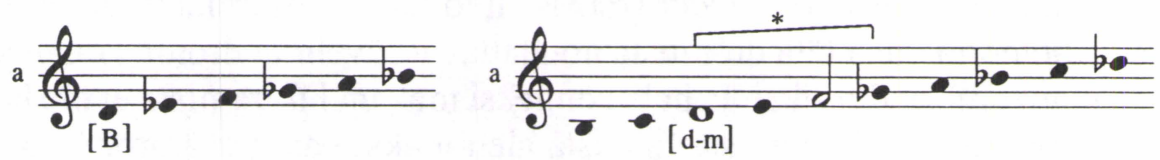

Esimerkki 12. a) I bambesan lauluosuuden asteikko d-pohjaisena van Stratenin mukaan sekä b) dromos sabah asteikkona.

Finaliksen transponointi d:hen hämärtää I bambesan asteikkorakenteen. Sävelmän logiikan mukainen finalis olisi ollut $\mathrm{f}^{1}$. Van Straten on tullut analysoineeksi D-duuripohjaisen segah-sävelmän sijasta dromos sabahiksi arvelemaansa B-duuripohjaista segah-sävelmää. Omasta analyysistani käy selvästi ilmi, että kappaleen dromos on segah (esim. 13).

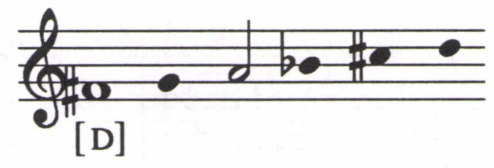

Esimerkki 13. I bambesan lauluosuuden D-duuripohjainen asteikko oman tulkintani mukaan.

Toinen kiintoisa esimerkkikappale on Papazoglun sävellys I lahanades (esim. 14). Analyysissaan van Straten $(1989,81)$ transponoi lauluosuuden finaliksen jälleen d-pohjaiseksi: $\left(b-c \#^{1}\right) d^{1}-b^{1}\left(e^{1}\right)-f^{1}-g^{1}-a b^{1} / a^{1}-b^{1}$ (esim. 15). Kirjoittaja toteaa, että laulaja muuntelee sävelmää jatkuvasti, eikä hän ei ole

\footnotetext{
14 Van Straten ei seuraa yhden komman alennuksen vaikutusta muissa tasavireistetyissä makameissa. Komman tai kahden alennus ei riitä muuttamaan tasavireistettyä intervallia puolisävelaskeleen verran. Mikäli se riittäisi, asteikoltaan duuria muistuttava makam rast muuttuisi mollipohjaiseksi.
} 
pyrkinyt tarkkaan transkriptioon. Siksi nuotinnoksesta puuttuu asteikkoon päätynyt $\mathrm{e}^{1}$-sävel, jota transkriptiokorkeudella vastaisi $\mathrm{c}^{\sharp^{1}}$. Van Stratenin tulkinnan mukaan 3. aste eli $\mathrm{f}^{1}$ korostuu, ja 5 . aste on vuoroin alennettu, vuoroin palautettu. Kirjoittaja ei pysty tunnistamaan dromosta.

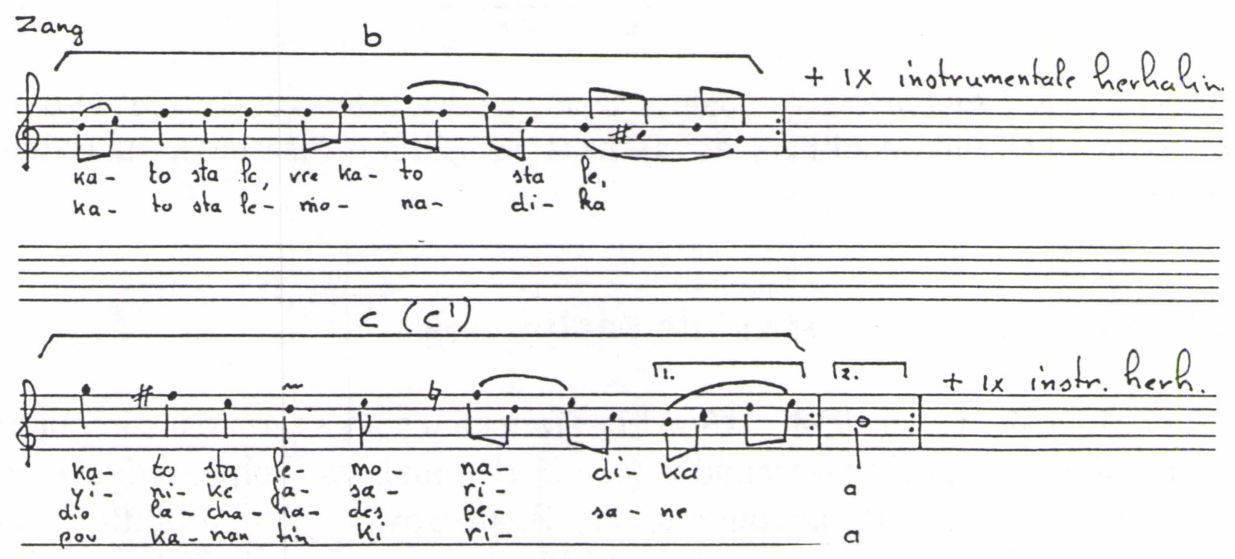

Esimerkki 14. Vangelis Papazoglun sävellyksen I lahanades lauluosuus van Stratenin $(1989,100)$ nuotintamana.

Oma tulkintani I lahanadesin asteikosta on esimerkki 16:n mukainen. Dromos on huzam A, joten sävelmästä löytyy makam segâh -asteikon perusmuoto (ks. myös Pennanen 1994a, 99). Nuotinnoksesta pois jäänyt harvoin esiintyvä sävel paljastuu güçlün johtosäveleksi (esim. 15a). Güçlün yläpuolinen rast-tetrakordi on ajoittain korvautunut buselik-tetrakordilla, mikä on tyypillistä makam segâhille (esim. 16b).

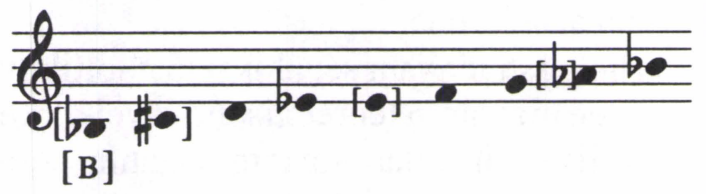

Esimerkki 15. I lahanades -kappaleen lauluosuuden asteikko d-pohjaisena van Stratenin $(1989,81)$ mukaan. 


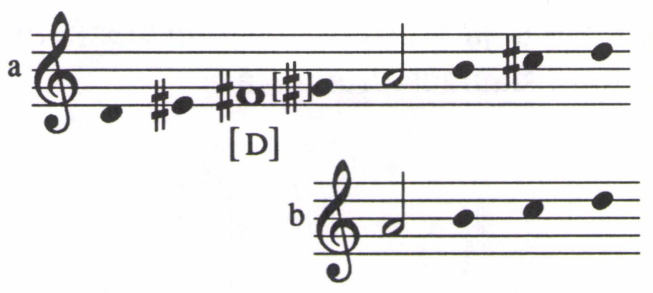

Esimerkki 16. I lahanades -kappaleen lauluosuuden asteikkorakenteet D-duuripohjaisena oman tulkintani mukaan: a) makam segâhin perusasteikko ja b) buselik-tetrakordi.

\section{Makamien segâh ja rast suhde analyysissa}

Samuel Baud-Bovyn (1938, 315-317) Dodekanesian saaristosta keräämän karpathoslaisen mandina-serenadin (esim. 17) analyysi kelpaa edustavaksi näytteeksi asteikkoajattelun ongelmista. Baud-Bovy pyrkii luokittelemaan aineistonsa mahdollisuuksien mukaan kirkkosävellajien avulla. Tämä on ymmärrettävää, sillä häntä edeltävä ranskankielinen tutkimus analysoi kreikkalaista musiikkia penta- ja tetrakordeista rakentuvien kirkkosävellajien sekä kromaattisten asteikkojen pohjalta (ks. Bourgault-Ducoudray 1876; idem. 1877; idem. 1879; Lambelet 1934). Baud-Bovy ei kirjoita sävelmien finaliksia vakiokorkeudelle. Myöskään samaa kirkkosävellajia seuraavat sävelmät eivät ole samassa sävellajissa.

Baud-Bovy tulkinnan mukaan serenadi seuraa fryygistä eli mi-asteikkoa (esim. 18). Hän selittää laatimansa asteikon toonikan $\left(\mathrm{h}^{1}\right)$ olevan fryygisen tetrakordin pohjasävel. Toonikan alapuolelle hän on merkinnyt sävelet $\mathrm{a}^{\sharp 1}, \mathrm{a}^{1} \mathrm{ja}$ $\mathrm{g}^{1}$. Yhdeksi asteikoksi kirjoitettuna makam segâhiin kuuluvat poikkeamat makam rastiin sulautuvat pelkäksi kromatiikaksi. Periaatteessa kirjoittajalla olisi ollut mahdollisuus ottaa huomioon poikkeama rast-pentakordiin, mikäli hän pitäisi sitä joonisena asteikkona.

Sävelmän tunnistaa helposti makam segâhiksi jo nuottikuvasta, koska BaudBovy on transponoinut sen makamin teoreettiselle sävelkorkeudelle. Analyysin kannalta olisi havainnollista kirjoittaa makam segâhin perusasteikko ja rastpentakordi erikseen (esim. 19).

Makam segâhin ja siihen sisältyvän makam rast -komponentin keskinäisen suhteen analyysia voisi verrata duurimollijärjestelmää noudattavan kappaleen analyysiin. Tutkija luultavasti ilmaisisi rinnakkaissävellajeista rakentuvan melodian asteikot erillisinä ja suhteessa toisiinsa. Hän ei transponoisi rinnakkaismollin toonikaa duurin toonikaan eikä toisaalta yhdistäisi melodian säveliä yhdeksi asteikoksi. 

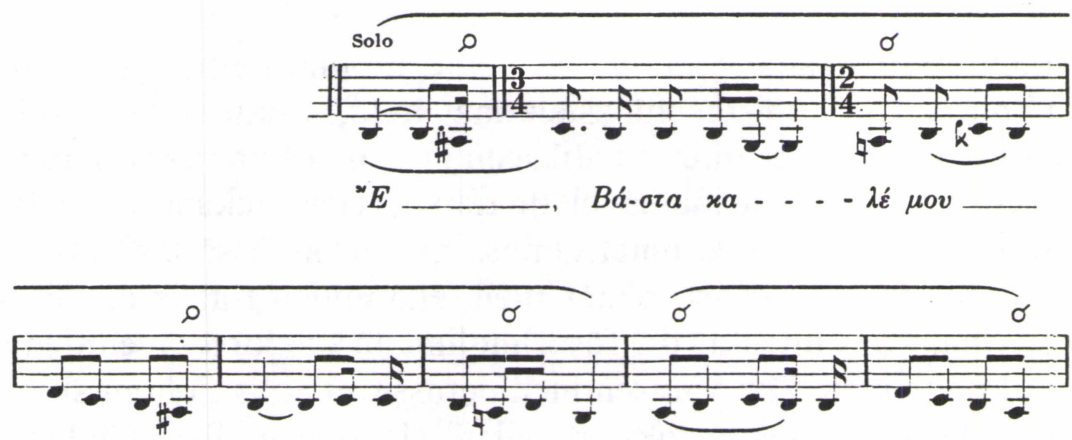

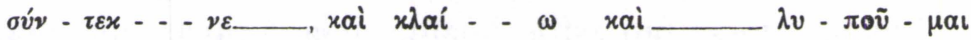
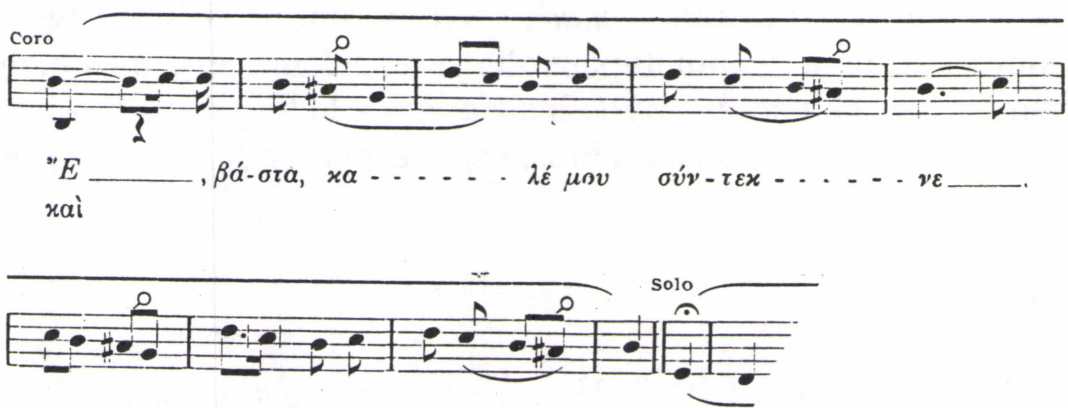

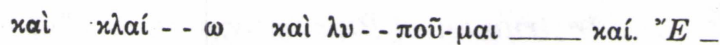

Esimerkki 17. Ote karpathoslaisesta mandina-serenadista (Baud-Bovy 1938, 315-316).

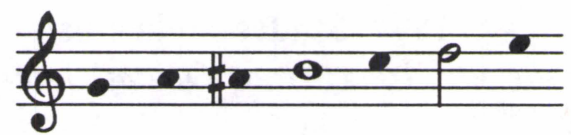

Esimerkki 18. Baud-Bovyn (1938, 315-316) mandina-serenadista johtama asteikko.
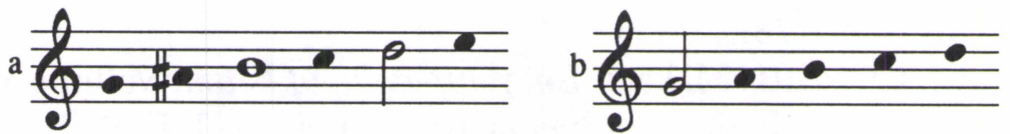

Esimerkki 19. Mandina-serenadin peruskomponentit eli a) segâhin perusasteikon osa ja b) rast-pentakordi oman tulkintani mukaan erikseen kirjoitettuina. 


\section{Päåtelmä}

Esittelemäni sävelmäanalyysit tuovat esille monia aiemman tutkimuksen heikkoja kohtia. On ilmeistä, että asteikkoajattelu, sointujen huomiotta jättäminen, toonikan samastaminen finalikseen ja saman finaliksen periaate tuottavat vaikeuksia etenkin segâh-sävelelle rakentuvien makamien analyysissa.

Ongelmien ratkaisu piilee omaksumassani käytännössä kirjoittaa dromos huzam A ja dromos segah -sävelmät siten, että niiden finalis on $\mathbb{H}^{*}$. Muiden dromosien finalis on kuitenkin $\mathrm{d}^{1}$. Tästä huolimatta kaikkien sävelmien I asteen sointu on d-pohjainen. D:n valitseminen perussävellajiksi johtuu siitä, että se on yleisin kolmikuoroisen buzukin sävellaji. Noudattamallani käytännöllä on monia etuja. Ensinnäkin se tuo esille finalikseltaan muista poikkeavien dromosien suhteen dromos rastiin ja madzoreen eli duuriin. Lisäksi tyypillisten modulaatioiden esittäminen nuottipaperilla ja rebetikan vertailu osmanien taidemusiikin kanssa helpottuu. Myös huzam A:sta kehittyneen huzam B:n ja makam müstearista kehittyneen dromosin suhde äitimoodeihinsa käy selväksi.

\section{Kirjallisuus}

Bartók, Béla \& Albert Lord 1978 [1951]. Yugoslav Folk Music. Volume One. Serbo-Croatian Folk Songs and Instrumental Pieces from the Milman Parry Collection. Benjamin Suchoff (ed.). New York: State University of New York Press.

Baud-Bovy, S. 1938. Tragudia ton Dodekanison. Tomos B. Ekdosis musiku laografiku arhiu. Athine: Vivliopolion I. N. Sideri.

Bourgault-Ducoudray, L.-A. 1876. Souvenirs d'une mission musicale en Grèce et en Orient. Paris: Libraire Hachette et $\mathrm{C}^{\text {ie }}$.

Bourgault-Ducoudray, L.-A. 1877. Études sur la musique ecclésiastique grecque. Mission musicale en Grèce et en Orient. Janvier-Mai 1875. Paris: Libraire Hachette et $C^{\text {ie }}$.

Bourgault-Ducoudray, L.-A. 1879. Conférence sur la modalité dans la musique grecque. Paris: Imprimerie Nationale.

Bukuvalas, Dimitris 1991. Buzuki. I tehniki tou ke i didaskalia tis. Me idiko sistima simiografias. Tomos tritos. Athine: Dim. Bukuvalas.

Cazden, Norman 1971. A Simplified Mode Classification for Traditional Anglo-American Song Tunes. Yearbook of the International Folk Music Council Vol. 3, 45-78.

Chabrier, J.-Cl. Ch. 1991. Makām. Encyclopaedia of Islam. Volume VI. New Edition, 96-104. C. E. Bosworth et al. (eds.). Leiden: J. E. Brill.

Chianis, Sotirios 1980. Greece IV, Folk Music. The New Grove Dictionary of Music and Musicians, 675-682. Stanley Sadie (ed.). Macmillan: London. 
Ciobanu, Gheorge 1969. Les modes chromatiques dans la musique populaire roumaine. Bulletin de l'Institut de musique de l'Académie bulgare des sciences $13,385-394$.

Dietrich, Eberhard 1987. Das Rebetiko. Eine Studie zur städtischen Musik Griechenlands. Beiträge zur Ethnomusikologie 17. Verlag der Musikaliehandlung Karl Dieter Wagner. Hamburg.

Džimrevski, Borivoje 1985. Čalgiskata tradicija vo Makedonija. Makedonsko narodno tvoreštvo orska i instrumentalna narodna tradicija. Kniga 4. Skopje: Makedonska Kniga.

Džudžev, Stojan 1970. Bălgarska narodna muzika. Učebnik. Tom I. Sofija: Nauka i izkustvo.

Elschek, Oskar 1977. Zum gegenwärtigen Stand der Volksliedanalyse und Volksliedklassifikation: Ein Forschungsbericht der Study Group of Folk Music der I.F.M.C. Yearbook of the International Folk Music Council Vol. 8, 21-34.

Frye, Ellen 1973. The Marble Threshing Floor. A Collection of Greek Folksongs. Publications of the American Folklore Society. Memoirs, vol. 57. Austin-London: The University of Texas Press.

Hornbostel, Erich M. von 1913. Melodie und Skala. Jahrbuch der Musikbibliothek Peters XIX, 11-23. Leipzig: C. F. Peters.

Huttunen, Matti 1993. Systematiikan ja historian yhteys Ilmari Krohnin tieteellisessä tuotannossa. Musiikki 3-4/1993, 95-117.

Idelsohn, Abraham 1914. Die Maqamen der arabischen Musik. Sammelbände der Internationalen Musik-Gesellschaft 15 (1913-14). 1-63.

Idelsohn, Abraham 1929. Jewish Music in its Historical Development. New York: Holt, Rinehart and Wilson.

Karas, Simonos I. 1989. Armonika. Sillogos pros diadosin tin ethnikis musikis. Athine.

Kremenliev, Boris A. 1952. Bulgarian-Macedonian Folk Music. BerkeleyLos Angeles.

Kutsothanasis, Vasilis 1989. Laiki dromi ke avtoshediasmi 'taksimia'. Athina: Vasilis Kutsothanasis.

Kutsothanasis, Vasilis 1990. Ta rebetika tragudia se notes ke stihus. Vivlio pembto. Athina: Vasilis Kutsothanasis.

Lambelet, Georges 1934. La musique populaire grecque. Chants et danses. Athènes: $\mathrm{M}$. Constantinidès.

Manuel, Peter 1989. Modal Harmony in Andalusian, Eastern European, and Turkish Syncretic Musics. Yearbook for Traditional Music vol. 21, 70-94. Michaelis, Solon 1954. Folk Music: Greek. Grove's Dictionary of Music and Musicians. 5th edition, 268-277. Eric Blom (ed.). London: Macmillan \& Co. Nettl, Bruno 1985. The Western Impact on World Music: Change, Adaptation and Survival. New York-London: Schirmer Books. 
Oramo, Ilkka 1978. Melodia ja sävelasteikko. Suomen tieteen ulottuvuuksia. Tieteen päivät 10.-12.1.1977, 352-368. Risto Kautto (toim.). Porvoo Helsinki - Juva: WSOY.

Pajatis, Haralambos 1992. Laiki dromi. Ekdosi veltiomeni. Athina: Fagotto. Piston, Walter 1950. Harmony. London: Victor Gollancz Ltd.

Pennanen, Risto Pekka 1992. Akkulturaatio Bosnian muslimien musiikissa. Etnomusikologian vuosikirja 1991-92, 224-241. Erkki Pekkilä (toim.). Helsinki: Suomen etnomusikologinen seura.

Pennanen, Risto Pekka 1994a. Moodit elvytetyn rebetikan kirjallisuudessa. Etnomusikologian vuosikirja 6, 87-102. Erkki Pekkilä (toim.). Helsinki: Suomen etnomusikologinen seura.

Pennanen, Risto Pekka 1994b. Kreikkalaisen kaupunkimusiikin länsimaistuminen - näkökulma väärinkuulemisen historiaan. Musiikin Suunta 2/1994, 37-52.

Powers, Harold S. 1980. Mode. The New Grove Dictionary of Music and Musicians 12, 376-450. Stanley Sadie (ed.). London-Washington-Hong Kong: Macmillan.

Powers, Harold S. 1992. Modality as a European Cultural Construct. Secondo convegno europeo di analisi musicale vol. I, 207-219. Rossana Dalmonte et al. (eds.). Trento: Università degli studi di Trento.

Reinhard, Kurt \& Ursula Reinhard 1984. Musik der Türkei. Band 1: Die Kunstmusik. Taschenbücher zur Musikwissenschaft 95. Wilhelmshaven: Heinrichshofen's Verlag.

Rouanet, J. 1922. La musique arabe. Encyclopédie de la musique et Dictionnaire de Conservatoire I/v, 2676-2939. Albert Lavignac (ed.). Paris: Delagrave.

Salmenhaara, Erkki 1970. Soinnutus. Harmoninen ajattelu tonaalisessa musiikissa. Helsinki: Otava.

Signell, Karl L. 1977. Makam. Modal Practice in Turkish Art Music. Washington: Asian Music Publications.

Straten, Hans van 1989. Rebetiko: Griekse stadmuziek met een turkse basis. Een studie naar de muzikale aspecten van de rebetiko. Universiteit van Amsterdam. Painamaton pro gradu -työtä vastaava tutkielma.

Suliţeanu, Ghisela 1976. Muzica dansurilor populare din Muscel-Argeş. Bucureşti: Editura Muzicală.

Trærup, Birthe 1970. East Macedonian Folk Songs. Contemporary Traditional Material from Maleševo, Pijanec and the Razlog District. Acta Ethnomusicologica Danica No. 2. Copenhagen: Akademisk Forlag.

Yekta Bey, Rauf 1922. La musique turque. Encyclopedie de la musique et Dictionnaire de Conservatoire I/v, 2945-3064. Albert Lavignac (ed.). Paris: Delagrave.

Zannos, Iannis 1990. Intonation in Theory and Practice of Greek and Turkish Music. Yearbook for Traditional Music Vol. 22, 42-59. 
Žganec, Vinko 1956. Die Elemente der jugoslawischen Folklore-Tonleitern im serbischen liturgischen Gesange. Studia Memoriae Belae Bartók Sacra, 349-363. Budapest: Aedes Academiae Scientiarum Hungaricae.

Özkan, İsmail Hakkı 1984. Türk mûsikîsi nazariyat1 ve usûlleri. Kudüm velveleri. İstanbul: Ötüken Neşriyat.

Äänite

EMI 14C 13471296, 40 hronia Papaioannu. 1983. 